\title{
Influence of slag composition on the hydration of alkali-activated slags
}

\author{
Frank Winnefeld ${ }^{\mathrm{a} *}$, Mohsen Ben Haha ${ }^{\mathrm{a}, 1}$, Gwenn Le Saout ${ }^{\mathrm{a}, 2}$, Mercedes Costoya ${ }^{\mathrm{b}}$, \\ Suz-Chung $\mathrm{Ko}^{\mathrm{b}}$ and Barbara Lothenbach ${ }^{\mathrm{a}}$ \\ ${ }^{a}$ Empa, Swiss Federal Laborqtories for.Materials Science and Technology Laboratory for
Concrete and Construction Chemistry, UUberlandstrasse 129,8600 Dübendorf, Switzerland; \\ ${ }^{b}$ Holcim Technology Ltd, Innovation R\&D, Im Schachen, 5113 Holderbank, Switzerland
}

\begin{abstract}
The hydration of different blast-furnace slags with sodium metasilicate or $\mathrm{NaOH}$ as activator was investigated. Sodium metasilicate shows poor strength after 1 day, but high strength after 7 days and beyond, whereas $\mathrm{NaOH}$ activation leads to high strength after 1 day, but only moderate strength development at later ages. At the same hydration degree, sodium metasilicate activation gives a much higher compressive strength than $\mathrm{NaOH}$ activation. This is due to the formation of a dense hydration product in the $\mathrm{NaOH}$-activated system at the early age, which leads to a more porous microstructure than in the case of sodium metasilicate. A higher $\mathrm{MgO}$ content in the slags is beneficial with respect to faster hydration kinetics and a more rapid strength development. Increasing $\mathrm{Al}_{2} \mathrm{O}_{3}$ contents lead to slightly slower hydration kinetics and slightly lower compressive strengths. The best correlation between compressive strength and slag composition was found using the extended basicity $(\mathrm{CaO}+\mathrm{MgO}) / \mathrm{SiO}_{2}$ index.
\end{abstract}

Keywords: alkali-activated slag; activator; slag chemistry; hydration degree; compressive strength; porosity

\section{Introduction}

Due to the climate debate there is a need for using different types of cement, which produce less greenhouse gases during their manufacturing than ordinary Portland cement.[1-5] In Portland cement technology a wide variety of industrial by-products are used as supplementary cementitious materials, including fly ash from coal combustion, ground-granulated blast furnace slag from iron production, and silica fumes from ferrosilicon production.[6] However, these generally replace only a portion of the Portland cement in concrete, typically in the order of $10-50 \%$ (and sometimes more like in the case of ground granulated blastfurnace slag), as higher replacements are often linked to a reduced performance and are usually not allowed in the cement and concrete standardization documents.

Thus, there is an increasing interest in the development, manufacturing, and applications of binders free of Portland cement and, when possible, made entirely or almost entirely from local secondary materials, with low-energy and low $\mathrm{CO}_{2}$ emissions. Alkali-activated binders are, besides other cementitious materials like supersulfated slag cements or calcium

*Corresponding author. Email: frank.winnefeld@empa.ch

${ }^{1}$ Now at Heidelberg Technology Center GmbH, Rohrbacher Str. 95, 69181 Leimen, Germany.

${ }^{2}$ Now at Ecole des Mines d'Alès, 6 avenue de Clavières, 30319 Alès cedex, France. 
sulfoaluminate cements, one of such potential alternatives to Portland cement.[4,5,7-18] They combine high $\mathrm{CO}_{2}$ savings and use of industrial byproducts with good performance in engineering properties like high compressive strength and high durability e.g. with respect to acid attack or fire exposure.[5,14,15,18]

A possible Portland cement free binder can be obtained by the activation of ground-granulated blast-furnace slag by alkaline solutions, e.g. alkali silicates, hydroxides, or carbonates. Such alkali activated slags can have high-strength development and using the adequate activators can lead to rapid setting and hardening, good durability and high resistance to chemical attack.[5,14,15,18-21] The main hydration products are calcium silicate hydrates containing aluminum $(\mathrm{C}-\mathrm{A}-\mathrm{S}-\mathrm{H})$ with a low $\mathrm{Ca} / \mathrm{Si}$ ratio $(\approx 1)$, a hydrotalcite-like phase, and in some cases also an AFm phase, most likely strätlingite.[18,19,22-30] Many variables influence the reaction of alkali-activated slags such as slag fineness and chemical composition, type, and concentration of the alkaline activator, water/binder $(\mathrm{w} / \mathrm{b})$ ratio, temperature, or $\mathrm{pH} .[18-38]$

The present paper is focused on one of these parameters, namely the chemical composition of the slag and its impact on hydration and strength development. The influence of the chemical composition of the blast-furnace slag on the properties of slag-blended Portland cements has been widely studied since decades, see [17,3755] and references cited therein, and several characteristic values or moduli for suitable slags have been proposed (Table 1). Most of these values are focused on the basicity (ratio $\mathrm{CaO}$ / $\mathrm{SiO}_{2}=$ ratio of network modifier to network former). In some of the characteristic values, this "simple basicity" is

Table 1. Moduli describing the reactivity of blast-furnace slags.

\begin{tabular}{|c|c|}
\hline Formula & Comment \\
\hline$K_{1}=\frac{\mathrm{CaO}}{\mathrm{SiO}_{2}}$ & $\begin{array}{l}\text { Simple basicity, }>1 \text { for good (basic) slags, between } \\
0.50 \text { and } 2.0 \text { suitable for alkali activation }[16]\end{array}$ \\
\hline$K_{2}=\frac{\mathrm{Al}_{2} \mathrm{O}_{3}}{\mathrm{SiO}_{2}}$ & $\begin{array}{l}\text { Modulus of activity, between } 0.1 \text { and } 0.6 \text { suitable for } \\
\text { alkali activation [16] }\end{array}$ \\
\hline$K_{3}=\frac{\mathrm{CaO}+\mathrm{MgO}}{\mathrm{SiO}_{2}}$ & $\begin{array}{l}\text { Extended basicity, European Standard EN 197-1 [56] } \\
\text { requires a value of }>1\end{array}$ \\
\hline$K_{4}=\frac{\mathrm{CaO}+\mathrm{MgO}}{\mathrm{SiO}_{2}+\mathrm{Al}_{2} \mathrm{O}_{3}}$ & Extended basicity, $[47] \geq 1$ for good quality \\
\hline$K_{5}=\frac{\mathrm{CaO}+\mathrm{MgO}+1 / 3 \mathrm{Al}_{2} \mathrm{O}_{3}}{\mathrm{SiO}_{2}+2 / 3 \mathrm{Al}_{2} \mathrm{O}_{3}}$ & Extended basicity,[45] $\geq 1$ for good quality \\
\hline$K_{6}=\frac{\mathrm{CaO}+\mathrm{Al}_{2} \mathrm{O}_{3}-10}{\mathrm{SiO}_{2}+10}$ & Extended basicity according to [46] \\
\hline$K_{7}=\frac{\mathrm{CaO}+\mathrm{MgO}+\mathrm{Al}_{2} \mathrm{O}_{3}}{\mathrm{SiO}_{2}}$ & $\begin{array}{l}\text { Extended basicity,[45] below } 1.5 \text { poor, between } 1.5 \\
\text { and } 1.9 \text { good, above } 1.9 \text { very good quality }\end{array}$ \\
\hline$K_{8}=\frac{\mathrm{CaO} \cdot \mathrm{Al}_{2} \mathrm{O}_{3}}{\left(\mathrm{SiO}_{2}+\mathrm{Al}_{2} \mathrm{O}_{3}\right)^{2}}$ & $\begin{array}{l}\text { Index of reactivity,[38] should be } \geq 0.18 \text { for good } \\
\text { quality }\end{array}$ \\
\hline$K_{9}=\frac{\mathrm{CaO}+\mathrm{MgO}+\mathrm{Al}_{2} \mathrm{O}_{3}}{\mathrm{SiO}_{2}+\mathrm{TiO}_{2}\left(+\mathrm{P}_{2} \mathrm{O}_{5}+\mathrm{F}+\mathrm{MnO}\right)}$ & quality coefficient $[17,36]$ \\
\hline$K_{10}=\frac{\mathrm{CaO}+\mathrm{CaS}+0.5 \cdot \mathrm{MgO}+\mathrm{Al}_{2} \mathrm{O}_{3}}{\mathrm{SiO}_{2}+\mathrm{MnO}}$ & $\begin{array}{l}F \text {-value according to [44], should be } \geq 1.5 \text { for good } \\
\text { quality }\end{array}$ \\
\hline
\end{tabular}


modified by the introduction of other oxides, like $\mathrm{MgO}$, a network modifier (e.g. in the extended basicity according to EN 197-1 [56]). The role of $\mathrm{Al}_{2} \mathrm{O}_{3}$ can be both network former and network modifier. This is considered in a different way by the various moduli, as $\mathrm{Al}_{2} \mathrm{O}_{3}$ is sometimes added to $\mathrm{CaO}$, sometimes added to $\mathrm{SiO}_{2}$ or distributed between both oxides. The last option is indirectly done by the simple basicity, as besides $\mathrm{CaO}$ and $\mathrm{SiO}_{2}$ generally mainly $\mathrm{Al}_{2} \mathrm{O}_{3}$ is present in the slags. Also the ratio $\mathrm{Al}_{2} \mathrm{O}_{3} / \mathrm{SiO}_{2}$ is used as parameter to assess the reactivity of slag. Some other characteristic values also include minor oxides, like $\mathrm{MnO}$ or $\mathrm{P}_{2} \mathrm{O}_{5}$. In $[40,41]$, the impact of the most important oxides on slag reactivity in blends with Portland cement is summarized: higher $\mathrm{CaO}$ and lower $\mathrm{SiO}_{2}$ contents improve reactivity of the slag, which refers to the simple basicity. Higher $\mathrm{Al}_{2} \mathrm{O}_{3}$ contents have a positive impact on early strength ( 2 days), a moderate impact on 28 and 91 days strength, and in cases of high contents ( $>13$ mass-\%) a negative influence on long-term strength (>91 days). $\mathrm{MgO}$ does not seem to have the same positive impact as $\mathrm{CaO}$, as some authors report a positive influence on strength, others observe a decrease in strength at high ( $>13$ mass- $\%$ ) concentrations. $\mathrm{TiO}_{2}$ amounts above a level of about 1 mass- $\%$ lead to strength decrease.

The above-mentioned moduli are based on the application of blast-furnace slags in blends with Portland cement. However, there is much less information in literature on the impact of slag composition on binder properties under conditions of alkaline activation. Probably most studies on alkaliactivated slags are focusing on the activator and not on slag chemistry. Only few attempts have been made to correlate reactivity or (strength) performance with slag moduli, which is probably related to the wide range of possible activation conditions. Knowing that slags, which can easily activated in a cementitious environment, are already largely used, a better understanding of the effects of the chemical composition of the slag could indicate ways to use less reactive slags efficiently. Slags with a $\mathrm{CaO} / \mathrm{SiO}_{2}$ ratio between 0.50 and 2.0 and an $\mathrm{Al}_{2} \mathrm{O}_{3} / \mathrm{SiO}_{2}$ ratio between 0.1 and 0.6 are thought to be suitable for alkali activation.[16] These wide ranges are related probably as well to the different possibilities for alkaline activation, but may also be an indication of a certain insensitivity of slag chemistry towards alkaline activation conditions.

This paper assembles results from our previous studies, which have been focused on the influence of $\mathrm{MgO}$ and $\mathrm{Al}_{2} \mathrm{O}_{3}$ contents in alkali activated blastfurnace slags on hydration kinetics, hydrate assemblage, microstructure, and compressive strength.[25-27,29] When replacing $\mathrm{CaO}$ by $\mathrm{MgO}$ and simultaneously increasing $\mathrm{Al}_{2} \mathrm{O}_{3}$ content, the activity of the slag increases.[17] It has been shown that a small amount of crystalline phases in slags and/or the presence of minor elements such as $\mathrm{MgO}$ increase slag reactivity,[34,35,52,56] as observed by isothermal calorimetry and strength measurements on pastes. In a recent study [30], it is reported that with increasing $\mathrm{MgO}$ content the early hydration of a slag is decelerated, but the hydration degree at longer hydration times is increased. In addition, the authors found a decrease of carbonation depth with increasing slag $\mathrm{MgO}$ content.

In the case of $\mathrm{Al}_{2} \mathrm{O}_{3}$, a delay of the hydration reaction of alkali activated slags, which were mixed with externally added $\mathrm{Al}_{2} \mathrm{O}_{3}$, is reported.[57] The authors observed that the addition of a low amount of $\mathrm{Al}_{2} \mathrm{O}_{3}(2 \mathrm{wt} \%)$ increased the 7 and 28 days compressive strength, while the addition of $15 \mathrm{wt} \%$ or more did not further improve the mechanical properties. An increase of early compressive strength with increasing $\mathrm{Al}_{2} \mathrm{O}_{3}$ content in the slag is reported by [37]. The authors of [58] observed an increase in compressive 
strength especially at early ages with higher $\mathrm{Al}_{2} \mathrm{O}_{3}$ content in the case of $\mathrm{NaOH}$ activation, whereas with potassium silicate a decrease of compressive strength at all testing times was found.

\section{Materials and methods}

Eight different ground-granulated blastfurnace slags with different chemical compositions and ground to a comparable particle size using a laboratory ball mill were used in this study. The chemical composition of the slags was determined by X-ray fluorescence and X-ray diffraction (XRD) analyses (Rietveld method using $\mathrm{CaF}_{2}$ as internal standard). Particle size distribution and specific surface area were measured by laser diffraction and Blaine method, respectively.

The slags were activated either by $\mathrm{NaOH}$ or by sodium metasilicate (sodium silicate $\mathrm{Na}_{2} \mathrm{SiO}_{3} \cdot 5 \mathrm{H}_{2} \mathrm{O}$ ) using the same added $\mathrm{Na}_{2} \mathrm{O}$-equivalent of $2.9 \%$ referred to the slag in both cases and including the presence of additional $2.8 \mathrm{~g} \mathrm{SiO}_{2}$ per $100 \mathrm{~g}$ slag in the sodium metasilicate system. All pastes were hydrated at a w/b ratio of 0.42 (slags HA, LA) or 0.40 (slags M8, M11, M13, A7, A14, A17) including the chemically combined water of the activators at $20{ }^{\circ} \mathrm{C}$ in sealed conditions. After different hydration times, compressive strength measurements were performed as well as thermogravimetric analysis (TGA), $\mathrm{XRD}$, and scanning electron microscopy (SEM) on crushed samples after stopping the hydration with isopropanol. Chemically bound water was determined from the TGA data as weight loss between 30 and $600{ }^{\circ} \mathrm{C}$. For SEM analyses, the samples were impregnated in an epoxy resin, polished, and carbon-coated. Per sample and hydration time several hundred backscattered electron images (BSE) were gathered and used for the quantitative determination of coarse capillary porosity and hydration degree by image analysis (IA). $[59,60]$ The volume of coarser pores as determined by SEM-IA includes, depending on the magnification $(2500 \times)$ used, pore sizes in the range of $0.05-$ $5 \mu \mathrm{m}$. The hydration degree determined by this method agrees very well with data obtained by ${ }^{29} \mathrm{Si}$ nuclear magnetic resonance.[29] For more details of the experimental procedures, see [25-27,29]. Thermodynamic modeling was carried out using the geochemical software GEMS $[61,62]$ in combination with the cemdata2007 database.[63,64]

\section{Results and discussion}

\subsection{Characterization of the slags}

The composition of the slags has been reported previously [25-27] and is here

Table 2. Chemical composition in mass- $\%$ of the investigated slags.

\begin{tabular}{lcccccccc}
\hline & $\mathrm{HA}$ & LA & $\mathrm{M} 8$ & $\mathrm{M} 11$ & $\mathrm{M} 13$ & $\mathrm{~A} 7$ & A14 & A17 \\
\hline $\mathrm{CaO}$ & 36.5 & 39.4 & 35.8 & 34.6 & 33.4 & 39.1 & 36.0 & 35.0 \\
$\mathrm{SiO}_{2}$ & 37.4 & 41.2 & 38.2 & 37.1 & 36.4 & 41.6 & 38.2 & 37.2 \\
$\mathrm{Al}_{2} \mathrm{O}_{3}$ & 12.0 & 7.1 & 12.0 & 11.5 & 11.3 & 7.0 & 14.1 & 16.7 \\
$\mathrm{Fe}_{2} \mathrm{O}_{3}$ & 0.58 & 1.0 & 1.6 & 1.8 & 1.4 & 1.3 & 1.4 & 1.4 \\
$\mathrm{MgO}$ & 8.0 & 7.4 & 7.7 & 10.5 & 13.2 & 7.2 & 6.6 & 6.4 \\
$\mathrm{Na} 2$ & 0.40 & 0.57 & 0.41 & 0.40 & 0.52 & 0.49 & 0.49 & 0.48 \\
$\mathrm{~K}_{2} \mathrm{O}$ & 1.2 & 0.70 & 1.2 & 1.1 & 1.0 & 0.63 & 0.58 & 0.54 \\
$\mathrm{TiO}_{2}$ & 0.50 & 0.26 & 0.50 & 0.48 & 0.47 & 0.28 & 0.25 & 0.24 \\
$\mathrm{Mn}_{2} \mathrm{O}_{3}$ & 1.6 & 1.1 & 1.5 & 1.5 & 1.4 & 1.1 & 1.0 & 1.0 \\
$\mathrm{P}_{2} \mathrm{O}_{5}$ & 0.03 & $<0.01$ & 0.03 & 0.03 & 0.02 & 0.01 & 0.01 & 0.01 \\
$\mathrm{SO}_{3}{ }^{a}$ & 2.4 & 1.6 & 1.4 & 1.2 & 0.36 & 1.3 & 1.2 & 1.0 \\
$\mathrm{L.O.I.}^{\text {a }}$ & -0.41 & -0.98 & -0.80 & -0.86 & -0.40 & -0.91 & -0.50 & -0.49 \\
\hline
\end{tabular}

${ }^{a}$ Usually approximately $90 \%$ of the sulfur present in the slags occurs as sulfide.[65] Thus also a negative loss on ignition is measured due to oxidation of the sulfide. 
repeated for the convenience of the reader. The chemical composition of the slags (Table 2) varies between a $\mathrm{CaO}$ content of 33.4 and 39.4 mass- $\%$, a $\mathrm{SiO}_{2}$ content of 36.4 and 41.6 mass- $\%$, an $\mathrm{Al}_{2} \mathrm{O}_{3}$ content of 7.0 and 16.7 mass- $\%$, and an $\mathrm{MgO}$ content of 6.4 and 13.2 mass- $\%$. Glass content is high, between 94.2 and 99.0 mass-\% (Table 3). Among the various minor crystalline phases are merwinite and melilite. Simple basicity (Table 1) is between 0.91 and 0.96 , when calculated using the average glass composition, which can be derived from the bulk oxide composition and the contents of the crystalline phases. All slags can be considered as slightly acidic $\left(K_{1}<1\right)$; however when taking into account also the $\mathrm{MgO}$ content (extended basicity according to EN 197-1 [56]) the slags are slightly basic with $K_{3}$ between 1.10 and 1.27 and fulfill the requirements according to the aforementioned standard $\left(K_{3}>1\right)$. The ratio of $\mathrm{Al}_{2} \mathrm{O}_{3} / \mathrm{SiO}_{2}\left(K_{2}\right)$ varies between 0.17 and 0.45 . Both $K_{1}$ and $K_{2}$ are within the limits defined by [16] for slags suitable for alkali activation.
When taking into account the $\mathrm{Al}_{2} \mathrm{O}_{3}$ in the basicity according to the different formulas $K_{4}-K_{7}$, the quality assessment changes, e.g. all slags were classified as poor when using $K_{4}$, but mainly as good when using criteria $K_{5}$ and $K_{7}$. Except for two samples (LA and $\mathrm{A} 7$ with the lowest $\mathrm{Al}_{2} \mathrm{O}_{3}$ contents) the slags fulfill the requirement according to [39], but do not fulfill the $F$ value according to [45]. Thus, in agreement with [53], it can be stated that there is probably no simple formula to assess the reactivity of blast furnace slags.

The particle size distribution and the specific surface of the eight investigated slags (Table 4) are very similar, which makes the slags very suitable to study the effect of their chemical composition on hydration kinetics and strength development.

\subsection{Influence of the activator}

Figure 1 gives the compressive strength development of the slag pastes activated with sodium metasilicate and $\mathrm{NaOH}$.

Table 3. Phase composition in mass- $\%$ of the investigated slags.

\begin{tabular}{lcccccccr}
\hline & HA & LA & M8 & M11 & M13 & A7 & A14 & A17 \\
\hline $\begin{array}{l}\text { Akermanite } \\
\text { Anhydrite }\end{array}$ & 0.9 & 5.0 & & & & 3.1 & & \\
$\begin{array}{l}\text { Calcite } \\
\text { Larnite }\end{array}$ & 1.3 & & & & & 0.3 & 0.4 & 0.3 \\
Melilite & 3.7 & & & & & & & \\
Merwinite & & & 0.2 & 0.7 & 0.2 & & & \\
Iron & & & & 0.5 & 1.3 & & & \\
Amorphous & 94.2 & 95.0 & 99.8 & 98.9 & 98.5 & 96.0 & 99.0 & 99.0 \\
\hline
\end{tabular}

Table 4. Granular properties of the investigated slags.

\begin{tabular}{|c|c|c|c|c|c|c|c|c|}
\hline & HA & LA & M8 & M11 & M13 & A7 & A14 & A17 \\
\hline Density $\left(\mathrm{g} / \mathrm{cm}^{3}\right)$ & 2.88 & 2.92 & 2.92 & 2.93 & 2.94 & 2.90 & 2.88 & 2.87 \\
\hline Blaine value $\left(\mathrm{cm}^{2} / \mathrm{g}\right)$ & 5020 & 5030 & 4990 & 5070 & 5010 & 5020 & 4960 & 4990 \\
\hline 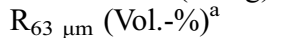 & 0.0 & 0.0 & 0.0 & 0.0 & 0.0 & 0.2 & 0.4 & 0.1 \\
\hline $\mathrm{R}_{45 \mu \mathrm{m}}\left({\text { Vol.- } \%)^{\mathrm{a}}}^{\mathrm{a}}\right.$ & 0.8 & 0.9 & 0.5 & 0.0 & 0.0 & 1.0 & 1.3 & 1.1 \\
\hline $\mathrm{R}_{18 \mu \mathrm{m}}\left(\mathrm{Vol}_{-\mathrm{-}} \%\right)^{\mathrm{a}}$ & 21.3 & 24.9 & 23.0 & 18.7 & 21.8 & 21.6 & 22.4 & 22.4 \\
\hline $\mathrm{R}_{3 \mu \mathrm{m}}(\mathrm{V} \mathrm{l} .-\%)^{\mathrm{a}}$ & 71.7 & 78.4 & 76.9 & 74.7 & 76.9 & 74.9 & 76.5 & 75.6 \\
\hline $\mathrm{D}_{50}(\mu \mathrm{m})^{\mathrm{b}}$ & 7.4 & 9.0 & 8.3 & 7.3 & 8.1 & 7.9 & 8.3 & 8.2 \\
\hline
\end{tabular}

${ }^{\mathrm{a}}$ Laser diffraction, fractions above $63,45,18$, and $3 \mu \mathrm{m}$, respectively.

${ }^{\mathrm{b}}$ Laser diffraction, mean particle diameter. 
(a)

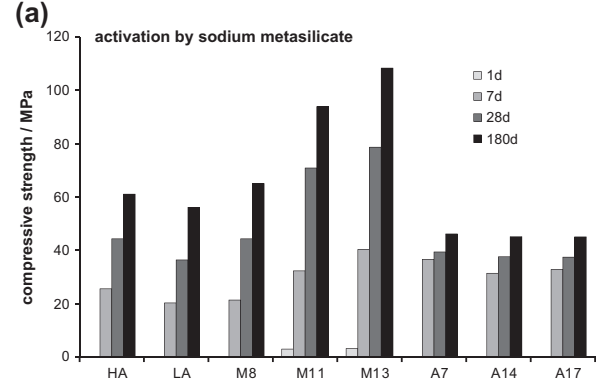

(b)

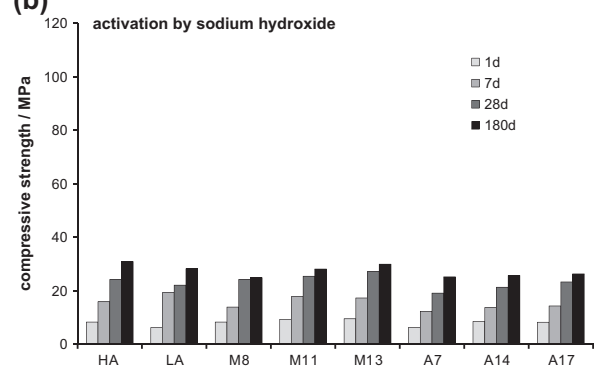

Figure 1. Compressive strength of the slag pastes activated with (a) sodium metasilicate and (b) sodium hydroxide. Data taken from [25-27]. Values after 90 and 360 days were omitted.

With sodium metasilicate activation, compressive strength after 1 day could not be measured with the exception of slags M11 and M13 with the highest MgO content. Between 1 and 7 days a rapid strength development occurs, reaching values between 20 and close to $40 \mathrm{MPa}$. After 180 days, compressive strength is between 45 and $110 \mathrm{MPa}$. Strength development is strongly depending on the slag composition (see below).

Pastes activated with $\mathrm{NaOH}$ show a compressive strength of maximum $10 \mathrm{MPa}$ after 1 day. Beyond 1 day, strength development is moderate; reaching about $30 \mathrm{MPa}$ after 180 days. Strength development is almost independent from slag composition.

The relation between compressive strength and hydration degree is given in Figure 2. The samples with $\mathrm{NaOH}$ reach after 1 day $(17-31 \%)$ and 7 days (23-37\%) higher hydration degrees than

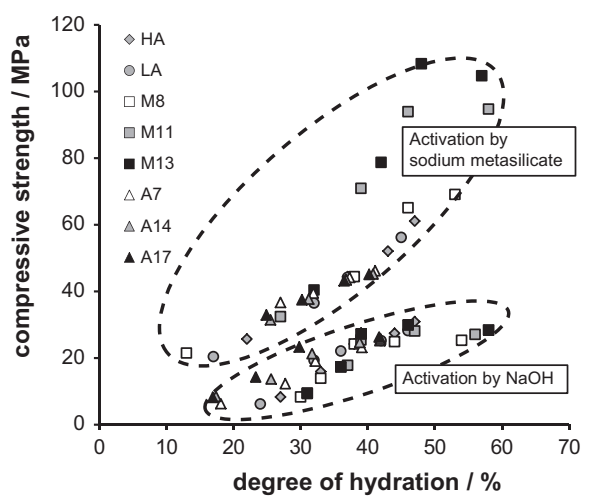

Figure 2. Compressive strength of the slag pastes vs. degree of hydration. Data taken from [25-27].

the pastes with sodium metasilicate (not measurable by SEM/BSE after 1 day, $13-32 \%$ after 7 days). The faster hydration kinetics with $\mathrm{NaOH}$ compared to sodium metasilicate can also be seen by conduction calorimetry.[26,27] Similar hydration degrees result for both activators after 180 days (sodium metasilicate $40-48 \%, \mathrm{NaOH} 42-47 \%$ ). From Figure 2, it can be derived that at the same hydration degree a higher compressive strength is reached with sodium metasilicate than with $\mathrm{NaOH}$. Within one activation system approximately, a linear relation between hydration degree and compressive strength is observed.

The amount of bound water is a parameter which can be potentially used monitoring the progress of hydration for a given activator. Its correlation with compressive strength is shown in Figure 3. The $\mathrm{NaOH}$ activated pastes show lower compressive strengths than those activated with sodium metasilicate at the same content of bound water, while within an activation system roughly a linear correlation between both parameters can be observed.

In all systems, $\mathrm{C}-\mathrm{A}-\mathrm{S}-\mathrm{H}$ incorporating aluminium and a hydrotalcite-like phase are the main hydration products.[25-27] The initial rate of reaction is 


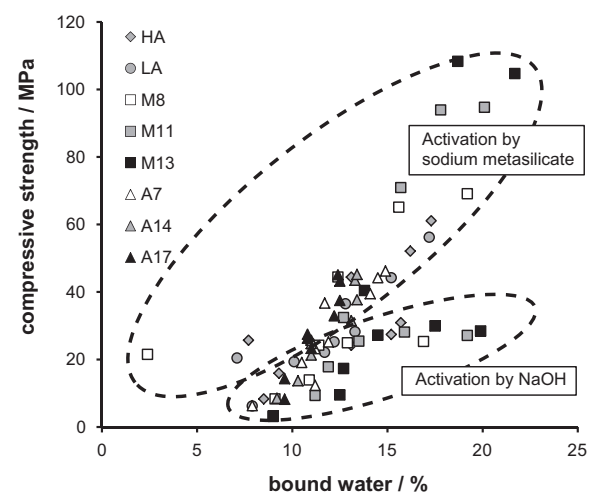

Figure 3. Compressive strength of the slag pastes vs. bound water. Data taken from [2527].

higher using $\mathrm{NaOH}$. During the fast initial hydration in the case of $\mathrm{NaOH}$ activation reaction a dense $\mathrm{C}-\mathrm{A}-\mathrm{S}-\mathrm{H}$ with, compared to the sodium metasilicate activated system, less chemically bound water is formed, the microstructure is coarser with a higher porosity, and the hydration products appear not well distributed throughout the matrix. This is evident from Figure 4 showing the microstructure of slag M13 with sodium metasilicate and $\mathrm{NaOH}$ activation, respectively, after 7 days of hydration.

Figure 5 shows the compressive strength vs. coarse capillary porosity. Both correlate very well, independently of the activator system used. From this, it can be

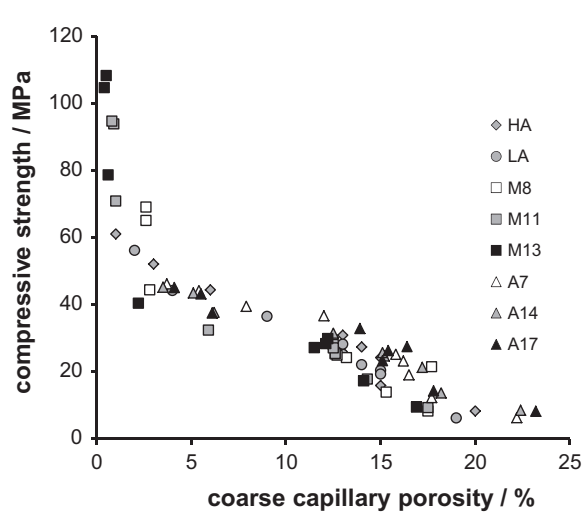

Figure 5. Compressive strength of the slag pastes vs. coarse capillary porosity. Data taken from [25-27].

concluded that the porosity of the system governs compressive strength. In the system activated with sodium metasilicate, the slag hydrates slowly and there is enough time for the hydration products to precipitate relatively uniformly throughout the interstitial space between the slag grains. This results in a lower porosity and much higher compressive strength at the same degree of slag reaction compared to the $\mathrm{NaOH}$ activated system. In the case of $\mathrm{NaOH}$, despite the continuous reaction, the increase in compressive strength and the decrease of coarse porosity is limited due to the formation of a very dense hydration product.
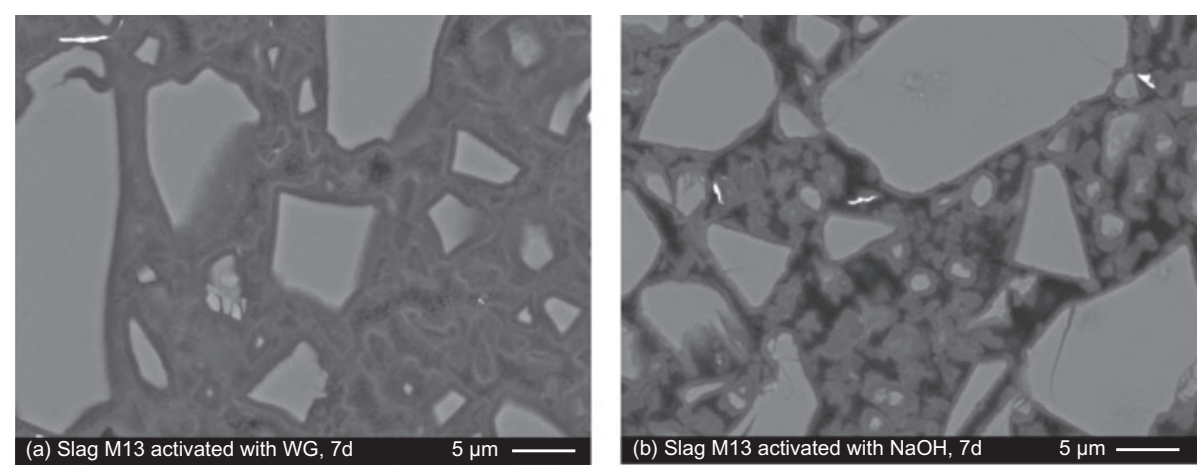

Figure 4. SEM images of slag M13 activated by (a) sodium metasilicate (WG) and (b) $\mathrm{NaOH}$, hydration time 7 days. 


\subsection{Influence of $\mathrm{MgO}$ content}

The slags M8, M11, and M13 show an increasing $\mathrm{MgO}$ content, while the contents of the other oxides differ only slightly.

In the case of sodium metasilicate activation, an increase of both early (1 and 7 days) and late strength (28 and 180 days) can be observed with increasing $\mathrm{MgO}$ content (Figure 1(a)). M11 and M13, show the by far highest compressive strengths among all slags. The increase of early hydration kinetics could also be observed by conduction calorimetry.[26] An increase of $\mathrm{MgO}$ content of the slag increases the hydration degrees determined by SEM (Figure 2) and decreases the coarse porosity (Figure 5). For M11 and M13 a very low coarse capillary porosity of $<1$ Vol.- $\%$ already at a sample age of 28 days was determined. It has to be kept in mind that pores with smaller diameter than $0.05 \mu \mathrm{m}$ cannot be detected by SEM-IA using the chosen experimental setup. Nevertheless, those two slags develop a very dense microstructure with low capillary porosity and a high compressive strength when activated with sodium metasilicate.

Experimental observations by XRD and energy disperse X-ray spectroscopy (EDX) analyses [26] show the same phase assemblage for slags M8, M11, M13 with the main hydration products $\mathrm{C}-\mathrm{A}-\mathrm{S}-\mathrm{H}$ and hydrotalcite-like phase, and in the case of the low $\mathrm{MgO}$ slag M8 also possibly traces of strätlingite.

Thermodynamic calculations indicate that the amount of hydrotalcite-like phase increases with increasing $\mathrm{MgO}$ content as shown on the example of $\mathrm{NaOH}$-activated slag (Figure 6(a)).

With sodium metasilicate the formation of a $\mathrm{C}-\mathrm{A}-\mathrm{S}-\mathrm{H}$ with a lower $\mathrm{Ca} / \mathrm{Si}$ ratio and $5 \%$ more $\mathrm{C}-\mathrm{A}-\mathrm{S}-\mathrm{H}$ is calculated when compared to $\mathrm{NaOH}$-activated systems.[26] The calculated $\mathrm{Ca} / \mathrm{Si}$ ratio in the $\mathrm{C}-\mathrm{A}-\mathrm{S}-\mathrm{H}$ is 1.05 for the $\mathrm{NaOH}-$
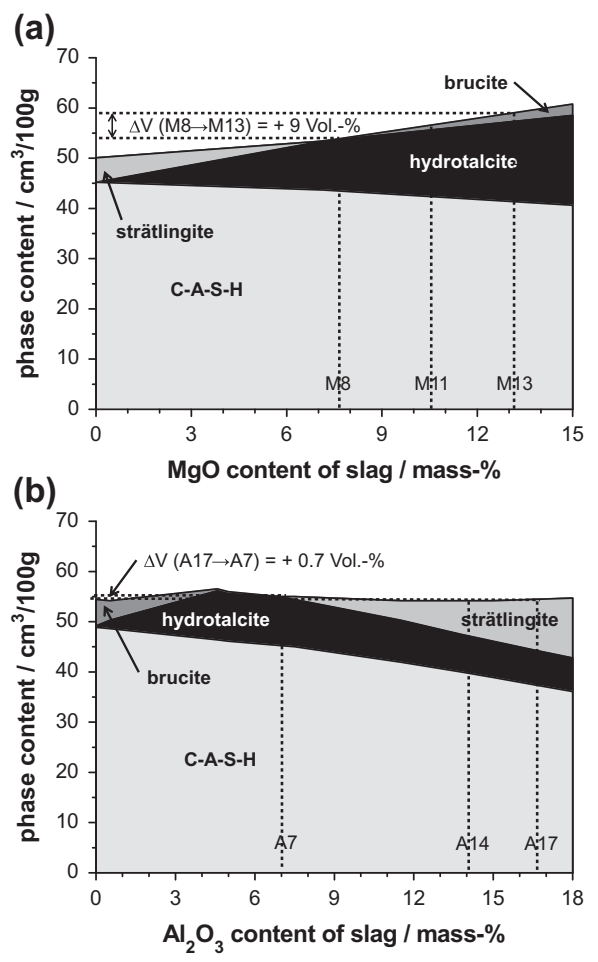

Figure 6. Thermodynamic modeling - influence of (a) $\mathrm{MgO}$ and (b) $\mathrm{Al}_{2} \mathrm{O}_{3}$ content on the calculated volume of the hydrates present in $\mathrm{NaOH}$ activated slag. Adapted from [26,27].

activated slags and 0.94 for the system activated with sodium metasilicate (due to the introduction of $\mathrm{SiO}_{2}$ with the activator) independent of the $\mathrm{MgO}$ content.[26] At high $\mathrm{MgO}$ content, a higher fraction of the available aluminum is bound by the hydrotalcite-like phase $\left(\mathrm{Mg}_{4} \mathrm{~A}\right.$ $\mathrm{l}_{2} \mathrm{O}_{7} \cdot 10 \mathrm{H}_{2} \mathrm{O}$ ). The remaining aluminum is incorporated in $\mathrm{C}-\mathrm{A}-\mathrm{S}-\mathrm{H}$. EDX analyses show that the Al uptake by $\mathrm{C}-\mathrm{A}-\mathrm{S}-\mathrm{H}$ decreases with increasing $\mathrm{MgO}$ content, which was taken into account by the GEMS model.[26] A higher hydrate volume is predicted with increasing $\mathrm{MgO}$ content due to the formation of more hydrotalcite and thus a lower porosity. Calculations indicate a $9 \%$ higher volume of the hydrates for M13 compared to M8, which could explain the higher strength with increasing $\mathrm{MgO}$ content in the slag. 
In the $\mathrm{NaOH}$-activated system, the higher $\mathrm{MgO}$ content leads to a slightly higher degree of reaction and thus to a slightly increased compressive strength at all ages (Figure 1(b)). The increase of the amount of hydrotalcite-like phase and thus the higher calculated volume at higher $\mathrm{MgO}$ contents has no significant effect on the compressive strength of the $\mathrm{NaOH}$ activated slags. Also the measured coarse porosity is not decreased in the presence of more hydrotalcite-like phase (Figure 5). Obviously in the case of $\mathrm{NaOH}$, the high content of coarse capillary porosity is the determining parameter regarding compressive strength, and the chemistry plays only a minor role.

\subsection{Influence of $\mathrm{Al}_{2} \mathrm{O}_{3}$ content}

The slags A7, A14, and A17 represent a series of slags with increasing $\mathrm{Al}_{2} \mathrm{O}_{3}$ contents, while the contents of the other oxides are comparable among the slags.

In the case of sodium metasilicate activation, a slightly decreasing strength after 7 and 28 days can be observed with increasing $\mathrm{Al}_{2} \mathrm{O}_{3}$ content, whereas all three slags reach a similar compressive strength after 180 days (Figure 1(a)). The faster early kinetics with lower $\mathrm{Al}_{2} \mathrm{O}_{3}$ content could also be confirmed by conduction calorimetry [27] and SEM (Figure 2). After 28 and 180 days similar hydration degrees are reached for all three slags. At these ages, the coarse porosities are very small and independent of the amount of $\mathrm{Al}_{2} \mathrm{O}_{3}$ present in the slag (Figure 5).

$\mathrm{C}-\mathrm{A}-\mathrm{S}-\mathrm{H}$, hydrotalcite-like phases as well as strätlingite for the slags with high $\mathrm{Al}_{2} \mathrm{O}_{3}$ content are observed by XRD and EDX analyses.[27] The Al uptake by $\mathrm{C}-\mathrm{A}-\mathrm{S}-\mathrm{H}$ increases and the $\mathrm{Mg} / \mathrm{Al}$ ratio of the hydrotalcite decrease with increasing $\mathrm{Al}_{2} \mathrm{O}_{3}$ content in the slag based on EDX analyses.[27] Thermodynamic calculations as shown in Figure 6(b) on the system with $\mathrm{NaOH}$ activation agree well with the experiments and predict the presence of $\mathrm{C}-\mathrm{A}-\mathrm{S}-\mathrm{H}$ and hydrotalcite, and at higher $\mathrm{Al}_{2} \mathrm{O}_{3}$ contents also the formation of strätlingite. $\mathrm{Al}$ intake into $\mathrm{C}-\mathrm{A}-\mathrm{S}-\mathrm{H}$ was modeled by GEMS based on EDX data. For both activators, the same hydrate assemblage is calculated, with the only difference that a slightly lower $\mathrm{Ca} / \mathrm{Si}$ ratio $(\mathrm{Ca} / \mathrm{Si}=0.9)$ in the $\mathrm{C}-\mathrm{S}-\mathrm{H}$ and $5 \%$ more $\mathrm{C}-\mathrm{A}-\mathrm{S}-\mathrm{H}$ is calculated in the presence of sodium metasilicate compared to $\mathrm{NaOH}$ activated systems $(\mathrm{Ca} / \mathrm{Si}=1.0)$.[27] With increasing $\mathrm{Al}_{2} \mathrm{O}_{3}$ content in the slag, the total amount of $\mathrm{C}-\mathrm{A}-\mathrm{S}-\mathrm{H}$ and hydrotalcite decreases, as the presence of more $\mathrm{Al}_{2} \mathrm{O}_{3}$ lowers the concentrations of the other oxides present in the slag. No relevant effect of $\mathrm{Al}_{2} \mathrm{O}_{3}$ content on the volume of the hydrates is predicted in case of both activators, and thus no significant changes in the coarse porosity at the same degree of hydration are expected and observed also experimentally.

The activation with $\mathrm{NaOH}$ leads as in the case of varying $\mathrm{MgO}$ contents to only minor changes in strength development with varying $\mathrm{Al}_{2} \mathrm{O}_{3}$ contents. Slightly faster early hydration kinetics up to sample age of 7 days with decreasing $\mathrm{Al}_{2} \mathrm{O}_{3}$ content could be observed by conduction calorimetry and SEM,[27] whereas after 180 days the same reaction degrees and coarse capillary porosities are reached for all three slags.

\subsection{Correlation between slag composition and compressive strength}

The various moduli describing the reactivity of blast-furnace slags were tested upon correlation with compressive strength, degree of hydration, bound water, and capillary porosity. It was found, as also stated already by [53] that most of the moduli do not show a good correlation with the properties mentioned above. The best correlation for the investigated samples is found for the extended 
basicity $K_{3}=(\mathrm{CaO}+\mathrm{MgO}) / \mathrm{SiO}_{2}$, which is used in European Standard EN 197-1 [56] to assess slag reactivity. This parameter takes into account $\mathrm{MgO}$ as strength contributing component. In the formula, $\mathrm{Al}_{2} \mathrm{O}_{3}$ is not present and thus it seems not to be considered at all. However, besides $\mathrm{CaO}, \mathrm{SiO}_{2}$, and $\mathrm{MgO}$, it is the main component of the slag, and one can argue that the equation for $K_{3}$ distributes $\mathrm{Al}_{2} \mathrm{O}_{3}$ between numerator and denominator and thus takes the amphoteric nature of $\mathrm{Al}_{2} \mathrm{O}_{3}$ into account.

Figure 7(a) shows that an increase of compressive strength with increasing $K_{3}$ can be observed in case of activation with sodium metasilicate, especially regarding the longer hydration times. After 7 days, there seems to be a minimum around $K_{3}=1.13$. This is mainly a kinetic effect, as those samples also show a minimum in the determined hydration degree (Figure 9(a)). Slags HA, M8, and A14 show a quite similar composition (see Table 2), but their compressive strength is quite different. The correlation between their $K_{3}$ and compressive strength is only good after 180 days. Thus, it seems to be a kinetic effect as well, as some minor components present in the slags like $\mathrm{TiO}_{2}$ or sulfide as well

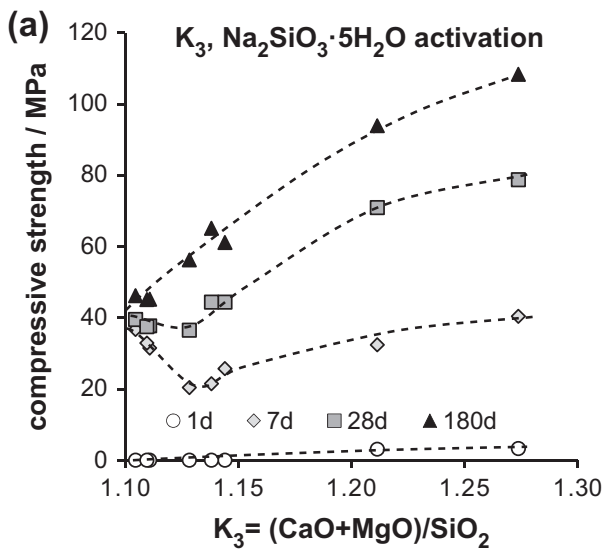

as the temperature history during slag formation and cooling, [41,42] which may lead to phase separation in the order of between 50 and $400 \mathrm{~nm}$ might influence slag dissolution kinetics.[41,42]

This correlation between $K_{3}$ and compressive strength is also valid in the case of $\mathrm{NaOH}$ activation. A slight increase of compressive strength with increasing $K_{3}$ is observed (Figure 7(b)), however the strength values are much lower in this case. Here, kinetic effects are not visible, which is due to the - compared to sodium metasilicate - harsher activation conditions in the case of $\mathrm{NaOH}$, providing a more rapid dissolution (see Figure 9(b) compared to Figure 9(a)).

The correlations with $K_{4}=(\mathrm{CaO}+$ $\mathrm{MgO}) /\left(\mathrm{SiO}_{2}+\mathrm{Al}_{2} \mathrm{O}_{3}\right), \quad K_{5}=(\mathrm{CaO}+$ $\left.\mathrm{MgO}+1 / 3 \mathrm{Al}_{2} \mathrm{O}_{3}\right) /\left(\mathrm{SiO}_{2}+2 / 3 \mathrm{Al}_{2} \mathrm{O}_{3}\right)$, $K_{7}=\left(\mathrm{CaO}+\mathrm{MgO}+\mathrm{Al}_{2} \mathrm{O}_{3}\right) /\left(\mathrm{SiO}_{2}\right) \quad$ and $K_{8}=\left(\mathrm{CaO} \cdot \mathrm{Al}_{2} \mathrm{O}_{3}\right) /\left(\mathrm{SiO}_{2}+\mathrm{Al}_{2} \mathrm{O}_{3}\right)^{2}$ for the slags activated with sodium metasilicate are shown in Figure 8. All four moduli are taking the effect of $\mathrm{Al}_{2} \mathrm{O}_{3}$ into account, but differently.

With increasing $K_{4}, K_{5}$ and $K_{7}$ an increase of compressive strength can be observed as a general trend. In the case of $K_{4}$ and $K_{5}$ (total $\mathrm{Al}_{2} \mathrm{O}_{3}$ assigned to the network formers in case of $K_{4}, 2 / 3$ of the

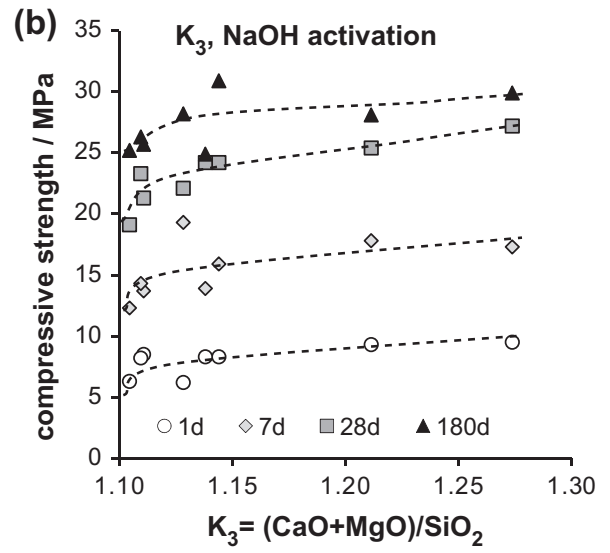

Figure 7. Correlation of $K_{3}=(\mathrm{CaO}+\mathrm{MgO}) / \mathrm{SiO}_{2}$, with compressive strength for slags activated with (a) sodium metasilicate and (b) sodium hydroxide. Note that the scales for compressive strength are chosen differently. Data taken from [25-27]. Lines are for eye-guide only. 
(a)

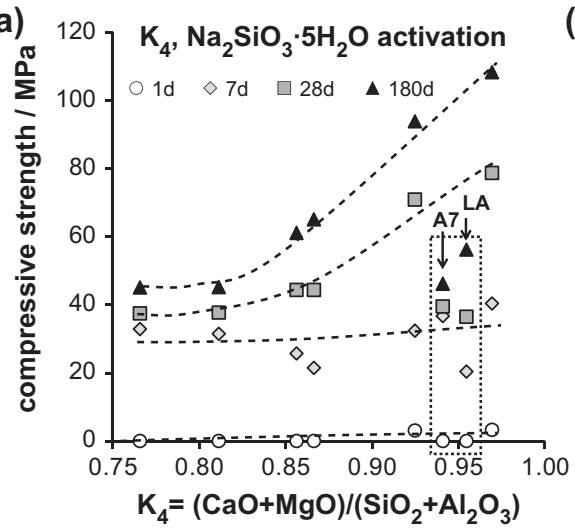

(c)

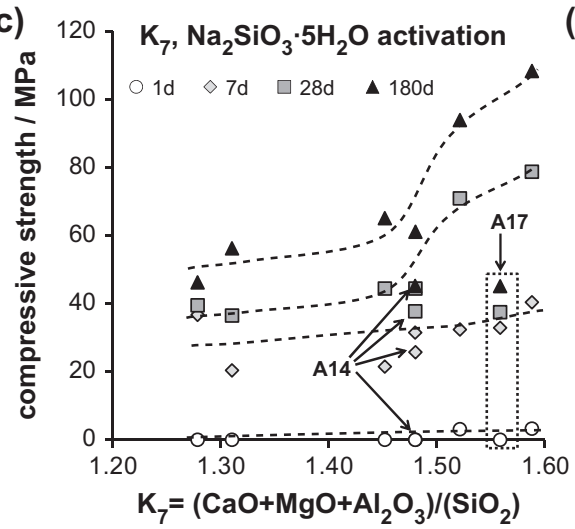

(b)

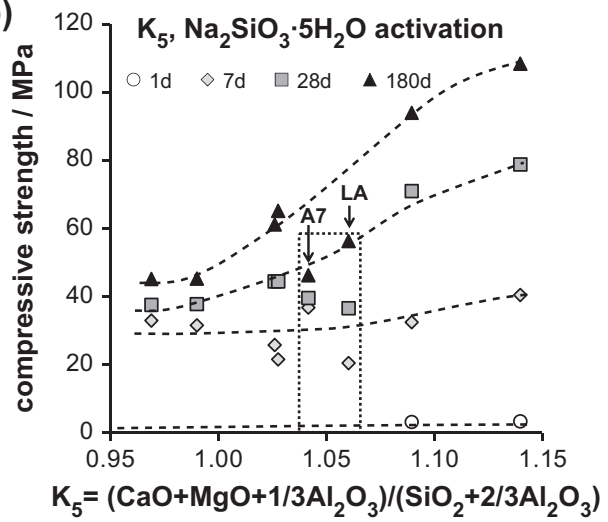

(d)

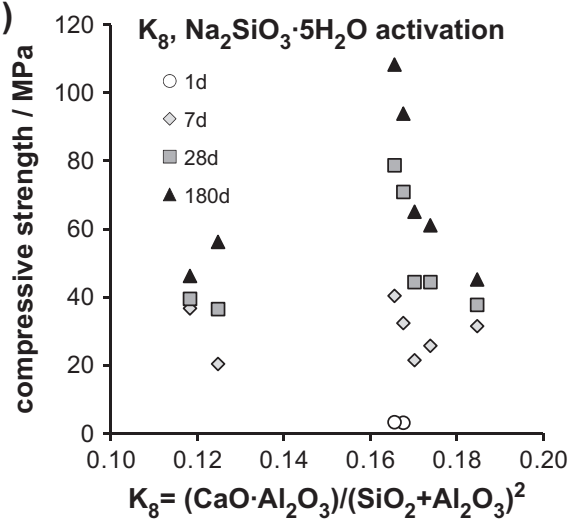

Figure 8. Correlation of (a) $K_{4}=(\mathrm{CaO}+\mathrm{MgO}) /\left(\mathrm{SiO}_{2}+\mathrm{Al}_{2} \mathrm{O}_{3}\right)$, (b) $K_{5}=(\mathrm{CaO}+\mathrm{MgO}+1 /$ $\left.3 \mathrm{Al}_{2} \mathrm{O}_{3}\right) /\left(\mathrm{SiO}_{2}+1 / 3 \mathrm{Al}_{2} \mathrm{O}_{3}\right)$, (c) $K_{7}=\left(\mathrm{CaO}+\mathrm{MgO}+\mathrm{Al}_{2} \mathrm{O}_{3}\right) / \mathrm{SiO}_{2}$ and (d) $K_{8}=\left(\mathrm{CaO} \cdot \mathrm{Al}_{2} \mathrm{O}_{3}\right) /$ $\left(\mathrm{SiO}_{2}+\mathrm{Al}_{2} \mathrm{O}_{3}\right)^{2}$ with compressive strength for slags activated with sodium metasilicate. Data taken from [25-27]. Lines are for eye-guide only.

$\mathrm{Al}_{2} \mathrm{O}_{3}$ in case of $K_{5}$ ), the slags with both low $\mathrm{Al}_{2} \mathrm{O}_{3}$ and low $\mathrm{MgO}$ content (A7, LA) do not correlate well as they show a too low compressive strength. This is probably related to the fact that in such slags not much of the hydrotalcite-like phase can be formed, which seems to show also some strength contribution. In the case of $K_{7}$ $\left(\mathrm{Al}_{2} \mathrm{O}_{3}\right.$ assigned to the network modifiers) the slags with both high $\mathrm{Al}_{2} \mathrm{O}_{3}$ and low $\mathrm{MgO}$ content (A14, A17) do not correlate well showing a too low compressive strength. In this case, the role of $\mathrm{Al}_{2} \mathrm{O}_{3}$ concerning strength is overestimated.

Thus, the amphoteric nature of the $\mathrm{Al}_{2} \mathrm{O}_{3}$ needs to be taken into account and can be represented well by $K_{3}=$
$(\mathrm{CaO}+\mathrm{MgO}) / \mathrm{SiO}_{2}$ in an indirect way. From this a general version of the equations $K_{4}, K_{5}, K_{7}$ can be derived as follows:

$$
\begin{gathered}
K_{3}^{\prime}=\frac{\mathrm{CaO}+\mathrm{MgO}+x \cdot \mathrm{Al}_{2} \mathrm{O}_{3}}{\mathrm{SiO}_{2}+(1-x) \cdot \mathrm{Al}_{2} \mathrm{O}_{3}} \\
\text { with } x=0 \ldots 1
\end{gathered}
$$

The parameter $x$ describes the distribution of $\mathrm{Al}_{2} \mathrm{O}_{3}$ between network modifier and network formers. In case of the slags investigated in this study the parameter $x$ is 0.5 for both activation systems, when $x$ is fixed in a way that the values of $K_{3}$ and $K_{3}^{\prime}$ are the same (which works pretty well for all eight slags at $x=0.5$ ) and thus show the same correlations with compressive strength. 
The use of $K_{8}$ (Figure $\left.9(\mathrm{~d})\right)$ as parameter to relate compressive strength to slag composition did not yield any correlation for the investigated systems.

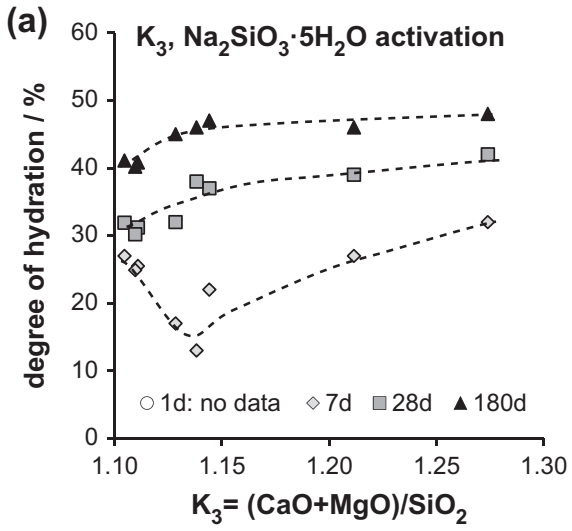

(c)

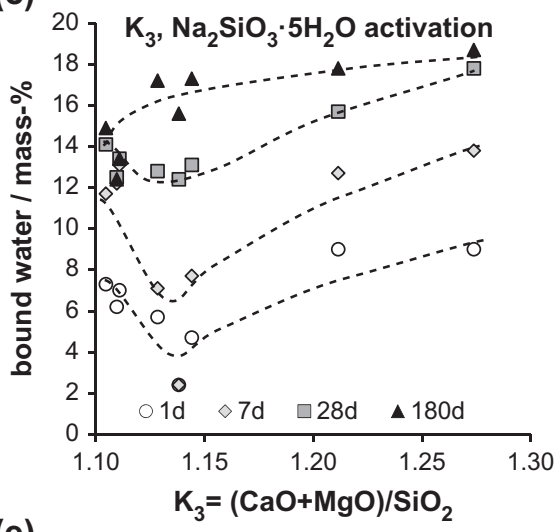

(e)

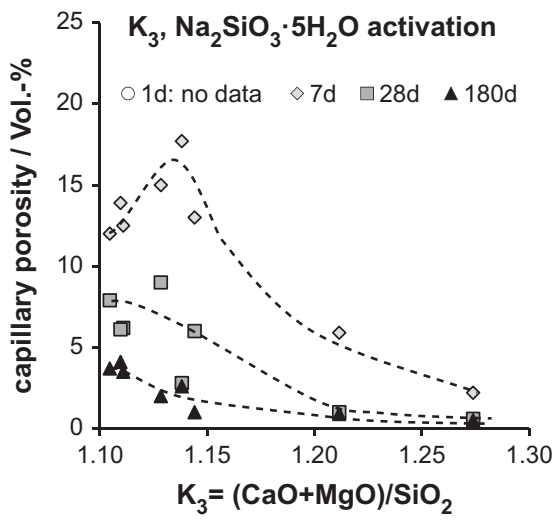

The correlation of hydration degree, bound water content and coarse capillary porosity with $K_{3}$ (or $K_{3}^{\prime}$ ) is shown in Figure 9 for the slags activated with

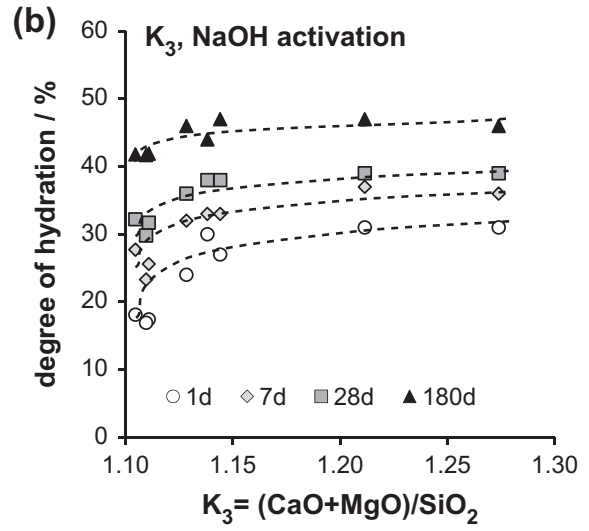

(d)

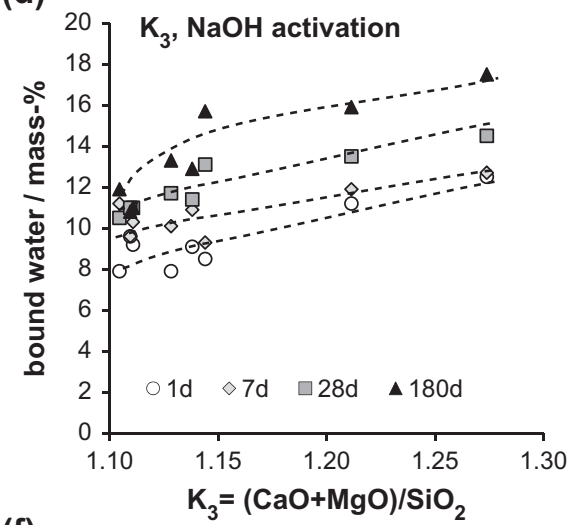

(f)

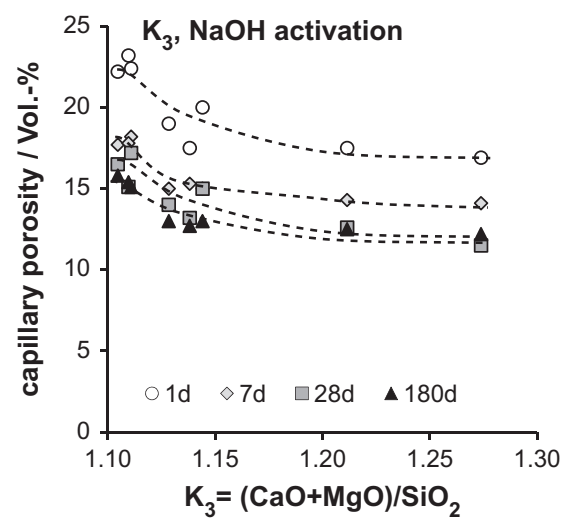

Figure 9. Correlation of $K_{3}=(\mathrm{CaO}+\mathrm{MgO}) / \mathrm{SiO}_{2}$ with (a) \& (b) degree of hydration, (c) \& (d) bound water and (e) \& (f) coarse capillary porosity for slags activated with sodium metasilicate and sodium hydroxide, respectively. Data taken from [25-27]. Degree of hydration was not measured after 1 day due to low strength. Lines are for eye-guide only. 
sodium metasilicate (Figure 9(a), (c), and (e)) and with sodium hydroxide (Figure 9(b), (d), and (f)). The degree of hydration is correlated positively with $K_{3}$ in case of both activators (Figure 9(a) and (b)). Also chemically bound water increases with increasing $K_{3}$ (Figure 9(c) and (d)) in both cases, with the exception of the sodium metasilicate activated slags at early hydration times ( 1 and 7 days). Those systems show a slow early kinetics as mentioned previously. As a consequence of the positive correlation of the parameters described above, coarse capillary porosity is negatively correlated with $K_{3}$ (Figure 9(e) and (f)) for both activation systems.

\section{Conclusions}

Eight different blast-furnace slags with varying chemical compositions, but very similar particle size distributions were investigated. The slags vary mainly in their $\mathrm{MgO}$ and $\mathrm{Al}_{2} \mathrm{O}_{3}$ contents. They were activated either by sodium silicate (sodium metasilicate) or by sodium hydroxide using the same $\mathrm{Na}_{2} \mathrm{O}$-equivalent added.

Independent of slag composition, it was found that sodium metasilicate activation gives slow early hydration kinetics during the first days, and strength after 1 day could not be measured for most of the samples. After 7 days and beyond a high compressive strength can be measured. When activated with $\mathrm{NaOH}$ the slags show a moderate compressive strength after 1 day, but strength after 180 days is much lower than in the case of sodium metasilicate. At the same hydration degree, a higher compressive strength is reached with sodium metasilicate than with $\mathrm{NaOH}$. During the fast initial hydration in the case of $\mathrm{NaOH}$ activation, a dense $\mathrm{C}-\mathrm{A}-\mathrm{S}-\mathrm{H}$ with less chemically bound water than in the sodium metasilicate activated system is formed. Thus the microstructure is coarser with a higher porosity. Compressive strength and coarse capillary porosity correlate very well, independently of the activator system used.

In the case of sodium metasilicate activation, an increase of both early and late strength can be observed with increasing $\mathrm{MgO}$ content, which is related to an increase of the hydration degree determined and a decrease of the coarse porosity. In addition, a higher hydrate volume is predicted by thermodynamic modeling with increasing $\mathrm{MgO}$ content and thus a lower porosity. In the $\mathrm{NaOH}-$ activated system, the higher $\mathrm{MgO}$ content leads to a slightly higher degree of reaction and thus to only a slightly higher compressive strength at all ages.

In the case of sodium metasilicate activation slightly slower early hydration kinetics and a slight reduction of strength after 7 and 28 days can be observed with increasing $\mathrm{Al}_{2} \mathrm{O}_{3}$ content. This is confirmed by thermodynamic modeling, which predicts no relevant effect of $\mathrm{Al}_{2} \mathrm{O}_{3}$ on the volume of the hydrates. Thus no significant changes in the coarse porosity at the same degree of hydration are expected as observed also experimentally. The activation with $\mathrm{NaOH}$ leads to only minor changes in strength development with varying $\mathrm{Al}_{2} \mathrm{O}_{3}$ contents. Slightly faster early hydration kinetics up to a sample age of 7 days with decreasing $\mathrm{Al}_{2} \mathrm{O}_{3}$ content could be observed.

Correlations between different "slag moduli" used to assess slag reactivity and compressive strength, chemically bound water, hydration degree, and coarse capillary porosity were tested. It was found that the ratio $K_{3}=(\mathrm{CaO}+\mathrm{MgO}) / \mathrm{SiO}_{2}$, the extended basicity according to $\mathrm{EN}$ 197-1, shows the best correlations. The role of $\mathrm{Al}_{2} \mathrm{O}_{3}$ which can be both network former and network modifier is considered here indirectly as besides $\mathrm{CaO}, \mathrm{MgO}$, and $\mathrm{SiO}_{2}$ generally mainly $\mathrm{Al}_{2} \mathrm{O}_{3}$ is present in the slags. This can be expressed in a general way by modifying $K_{3}$ to $K_{3}^{\prime}=\left(\mathrm{CaO}+\mathrm{MgO}+x \cdot \mathrm{Al}_{2} \mathrm{O}_{3}\right)$ $\left(\mathrm{SiO}_{2}+(1-x) \mathrm{Al}_{2} \mathrm{O}_{3}\right)$ with $x$ being a 
value between 0 and 1 . In case of the investigated activated slags, a value of 0.5 can be assigned to $x$. The extended basicity reflects also the positive impact of $\mathrm{MgO}$ on compressive strength. A positive correlation was found between extended basicity and strength, chemical bound water, hydration degree, and a negative correlation to coarse capillary porosity for both activators. However, these correlations refer only to the investigated systems, and it might be different in case other slags or activators are used.

\section{Acknowledgments}

The laboratory team of Empa is acknowledged for the experimental support.

\section{References}

[1] Gartner E. Industrially interesting approaches to "low- $\mathrm{CO}_{2}$ " cements. Cem. Concr. Res. 2004;34:1489-1498.

[2] Damtoft JS, Lukasik J, Herfort D, Sorrentino D, Gartner EM. Sustainable development and climate change initiatives. Cem. Concr. Res. 2008;38:115-127.

[3] Schneider M, Romer M, Tschudin M, Bolio H. Sustainable cement production - present and future. Cem. Concr. Res. 2011;41:642-650.

[4] Shi C, Jiménez A, Palomo A. New cements for the 21 st century: the pursuit of an alternative to Portland cement. Cem. Concr. Res. 2011;41:750-763.

[5] Juenger MCG, Winnefeld F, Provis JL, Ideker JH. Advances in alternative cementitious binders. Cem. Concr. Res. 2011;41:1232-1243.

[6] Lothenbach B, Scrivener K, Hooton RD. Supplementary cementitious materials. Cem. Concr. Res. 2011;41:1244-1256.

[7] Pacheco-Torgal F, Castro-Gomes J, Jalali S. Alkali-activated binders: A review: Part 1. Historical background, terminology, reaction mechanisms and hydration products. Constr. Build. Mater. 2008;22:1305-1314.

[8] Pacheco-Torgal F, Castro-Gomes J, Jalali S. Alkali-activated binders: A review. Part 2. About materials and binders manufacture. Constr. Build. Mater. 2008; 22:1315-1322.
[9] Davidovits J. Geopolymers. J. Thermal Anal. 1991;37:1633-1656.

[10] Krivenko PV. Alkaline cements. In: 9th International Congress on the Chemistry of Cements. Vol. IV; New Delhi (India); 1992. p. 482-488.

[11] Wang S-D, Pu X-C, Scrivener KL, Pratt PL. Alkali-activated slag cement and concrete: a review of properties and problems. Adv. Cem. Res. 1995;7:93102.

[12] Duxson P, Provis JL, Lukey GC, van Deventer JS. The role of inorganic polymer technology in the development of 'green concrete'. Cem. Concr. Res. 2007;37:1590-1597.

[13] Duxson P, Fernández-Jiménez A, Provis JL, Lukey GC, Palomo A, van Deventer JSJ. Geopolymer technology: the current state of the art. J. Mater. Sci. 2007;42: 2917-2933.

[14] van Deventer JSJ, Provis JL, Duxson P, Brice DG. Chemical research and climate change as drivers in the commercial adoption of alkali activated materials. Waste Biomass Valoriz. 2010; $1: 145-155$.

[15] Provis JL. Geopolymers and other alkali activated materials: why, how, and what? Mater. Struct. 2014;47:11-25.

[16] Talling B, Brandstetr J. Present state and future of alkali-activated slag concretes. In: Malhotra VM, editor. 3rd CANMET/ ACI Conference on Fly Ash, Silica Fume, Slag and Natural Pozzolans in Concrete; Trondheim (Norway); 1989. p. 1519-1545.

[17] Talling B, Krivenko P. Blast furnace slag - the ultimate binder. In Chandra S. Waste materials used in concrete manufacturing. Westwood (NJ): Noyes Publications; 1997. p. 235-289.

[18] Shi C, Krivenko PV, Roy D. Alkali-activated cements and concretes. New York (NY): Taylor \& Francis; 2006.

[19] Bernal SA, Provis JL, Fernández-Jiménez A, Krivenko PV, Kavalerova E, Palacios M, Shi C. Binder chemistry - highcalcium alkali-activated materials. In: Provis JL, van Deventer JSJ, editors. Alkali-activated materials: state-of-the-art report, RILEM TC 224-AAM. Dordrecht: Springer/RILEM; 2014. p. 59-91.

[20] Fernández-Jiménez A, Puertas F. Effect of activator mix on the hydration and strength behaviour of alkali-activated slag cements. Adv. Cem. Res. 2003;15: 129-136. 
[21] Fernández-Jiménez A, Palomo JG, Puertas F. Alkali-activated slag mortars: Mechanical strength behaviour. Cem. Concr. Res. 1999;29:1313-1321.

[22] Brough AR, Atkinson A. Sodium silicate-based, alkali-activated slag mortars: Part I. Strength, hydration and microstructure. Cem. Concr. Res. 2002;32: 865-879.

[23] Escalante-García JI, Fuentes AF, Gorokhovsky A, Fraire-Luna PE, Mendoza-Suarez G. Hydration products and reactivity of blast-furnace slag activated by various alkalis. J. Am Ceram. Soc. 2003;86:2148-2153.

[24] Burciaga-Díaz O, Escalante-García JI. Structure, mechanisms of reaction, and strength of an alkali-activated blast-furnace slag. J. Am. Ceram. Soc. 2013;96: 3939-9948.

[25] Ben Haha M, Le Saout G, Winnefeld F, Lothenbach B. Influence of activator type on hydration kinetics, hydrate assemblage and microstructural development of alkali activated blast-furnace slags. Cem. Concr. Res. 2011;41:301-310.

[26] Ben Haha M, Lothenbach B, Le Saout G, Winnefeld F. Influence of slag chemistry on the hydration of alkali-activated blastfurnace slag - Part I: Effect of $\mathrm{MgO}$. Cem. Concr. Res. 2011;41:955-963.

[27] Ben Haha M, Lothenbach B, Le Saout G, Winnefeld F. Influence of slag chemistry on the hydration of alkali-activated blastfurnace slag - Part II: Effect of $\mathrm{Al}_{2} \mathrm{O}_{3}$. Cem. Concr. Res. 2012;42:74-83.

[28] Gruskovnjak A, Lothenbach B, Holzer L, Figi R, Winnefeld F. Hydration of alkali-activated slag: comparison with ordinary Portland cement. Adv. Cem. Res. 2006;18:119-128.

[29] Le Saoût G, Ben Haha M, Winnefeld F, Lothenbach B. Hydration degree of alkali-activated slags: A 29Si NMR study. J. Am. Ceram. Soc. 2011;94: 4541-4547.

[30] Bernal SA, San Nicolas R, Myers RJ, Mejía de Gutiérrez R, Puertas F, van Deventer JSJ, Provis JL. MgO content of slag controls phase evolution and structural changes induced by accelerated carbonation in alkali-activated binders. Cem. Concr. Res. 2014;57:33-43.

[31] Lothenbach B, Gruskovnjak A. Hydration of alkali-activated slag: thermodynamic modelling. Adv. Cem. Res. 2007; 19:81-92.
[32] Puertas F, Martínez-Ramírez S, Alonso $\mathrm{S}$, Vázquez T. Alkali-activated fly ash/ slag cements: Strength behaviour and hydration products. Cem. Concr. Res. 2000;30:1625-1632.

[33] Puertas F, Fernández-Jiménez A. Mineralogical and microstructural characterisation of alkali-activated fly ash/slag pastes. Cem. Concr. Compos. 2003;25: 287-292.

[34] Stephan D, Tänzer R, Schmidt M. Alkali activation - an alternative to cements that contain clinker; part 1 . Cem. Int. 2010;8(1):72-85.

[35] Stephan D, Tänzer R, Schmidt M. Alkali activation - an alternative to cements that contain clinker; part 2. Cem. Int. 2010;8(2):74-81.

[36] Shi C, Li Y. Investigation on some factors affecting the characteristics of alkali-phosphorus slag cement. Cem. Concr. Res. 1989;19:527-533.

[37] Wang S-D, Scrivener KL, Pratt PL. Hydration products of alkali activated slag cement. Cem. Concr. Res. 1994;24: 1033-1043.

[38] Wang S-D, Scrivener KL. Hydration products of alkali activated slag cement. Cem. Concr. Res. 1995;25:561-571.

[39] Dron R. Structure and reactivity of glassy slags. In: 8th International Congress on the Chemistry of Cement. Vol. IV, 3; Rio de Janeiro (Brasil); 1986. p. 81-85.

[40] Ehrenberg A, Israel D, Kühn A, Ludwig H-M, Tigges V, Wassing W. Granulated blastfurnace slag: reaction potential and production of optimized cements, part 1 . Cem. Int. 2008;6(2):90-96.

[41] Ehrenberg A, Israel D, Kühn A, Ludwig H-M, Tigges V, Wassing W. Granulated blastfurnace slag: reaction potential and production of optimized cements, part 2. Cem. Int. 2008;6(3):82-92.

[42] Ehrenberg A. Hüttensand - Ein leistungsfähiger Baustoff mit Tradition und Zukunft, Teil 1 (Granulated blastfurnace slag - a high-performance construction material with tradition and future, part 1). Beton-Informationen. 2006;4:35-63.

[43] Ehrenberg A. Hüttensand - Ein leistungsfähiger Baustoff mit Tradition und Zukunft, Teil 2 (Granulated blastfurnace slag - a high-performance construction material with tradition and future, part 2). Beton-Informationen. 2006;5:67-95.

[44] Kocaba V. Development and evaluation of methods to follow microstructural development of cementitious systems 
including slags $[\mathrm{PhD}$ thesis]. EPF Lausanne (Switzerland); 2009.

[45] Keil F. Hochofenschlacke (Granulated blastfurnace slag). Düsseldorf (Germany): Verlag Stahleisen m.b.H; 1963.

[46] Lang E. Blastfurnace cements. In: Bensted J, Barnes P, editors. Structure and Performance of Cements. 2nd ed. London (UK): Spon Press; 2002. p. 310-325.

[47] Schwiete H-E, Dölbor F-C. Einfluß der Abkühlungsbedingungen und der chemischen Zusammensetzung auf die hydraulischen Eigenschaften von Hämatitschlacken (Influence of the cooling conditions and the chemical composition on the hydraulice properties of hematite slags). Forschungsberichte des Landes Nordrhein-Westfalen. No. 1186; Cologne (Germany); 1963.

[48] Smolczyk HG. Slag structure and identification of slags. In: 7th International Congress on the Chemistry of Cement. Vol. I; Paris, France; 1980. p. III-1/4-III$1 / 17$.

[49] Wassing W, Tigges VE. The significance of the silicate in granulated blastfurnace slags for the early strength of blastfurnace cement mortars and concretes. Cem. Int. 2008;6(2):98-109.

[50] Wassing W, Tigges VE. Improving the eraly strength of blastfurnace cement mortars and concretes by fixation of calcium silicate hydrogels with reactive aluminates. Cem. Int. 2008;6(5):62-79.

[51] Wassing W. Relationship between the chemical reactivity of granulated blastfurnace slags and the mortar standard compressive strength of the blastfurnace cements produced from them. Cem. Int. 2003;1(5):94-109.

[52] Demoulian E, Gourdin P, Hawthorn F, Vernet C. Influence of slag chemical composition and texture on their hydraulicity. In: 7th International Conference on the Chemistry of Cement. Vol. II; Paris (France); 1980. p. III-89-III-94.

[53] Smolczyk HG. The effect of the chemistry of the slag on the strengths of the blastfurnace cements. Zement-Kalk-Gips. 1978;31:294-296.

[54] Kollo H, Geiseler J. Beurteilung der Qualität von Hüttensand anhand von Kennwerten (Quality assessment of blastfurnace slag using characteristic values). Beton-Informationen. 1987;27: $48-51$.

[55] Douglas E, Brandstetr J. A preliminary study on the alkali activation of ground granulated blast-furnace slag. Cem. Concr. Res. 1990;20:746-756.

[56] European Standard EN 197-1. Cement Part 1: Composition, specifications and conformity criteria for common cements; 2011.

[57] Sakulich AR, Anderson E, Schauer CL, Barsoum MW. Influence of Si:Al ratio on the microstructural and mechanical properties of a fine-limestone aggregate alkali-activated slag concrete. Mater. Struct. 2010;43:1025-1035.

[58] Tänzer R, Stephan D, Ehrenberg A. Vergleich unterschiedlicher Hüttensande hinsichtlich ihrer Anregbarkeit durch Portlandzement und alternative alkalische Anreger (Comparison of different blastfurnace slags regarding their activation using Portland cement and alternative alkaline activators). In: Ludwig H-M, editor. 18. Internationale Baustofftagung (ibausil). Vol. 1; Weimar (Germany); 2012. p. 482-489.

[59] Ben Haha M, De Weerdt K, Lothenbach B. Quantification of the degree of reaction of fly ash. Cem. Concr. Res. 2010;40:1620-1629.

[60] Scrivener KL. Backscattered electron imaging of cementitious microstructures: understanding and quantification. Cem. Concr. Compos. 2004;26:935-945.

[61] Kulik DA, Wagner T, Dmytrieva SV, Kosakowski G, Hingerl FF, Chudnenko $\mathrm{kV}$, Berner U. GEM-Selektor geochemical modeling package: revised algorithm and GEMS3K numerical kernel for coupled simulation codes. Comput. Geosci. 2013;17:1-24.

[62] Wagner T, Kulik DA, Hingerl FF, Dmytrieva SV. GEM-Selektor geochemical modeling package: TSolMod library and data interface for multicomponent phase models. Can. Mineral. 2012;50: $1173-1195$.

[63] Lothenbach B, Matschei T, Möschner G, Glasser F. Thermodynamic modelling of the effect of temperature on the hydration and porosity of Portland cement. Cem. Concr. Res. 2008;38:1-18.

[64] Matschei T, Lothenbach B, Glasser F. Thermodynamic properties of Portland cement hydrates in the system $\mathrm{CaO}-$ $\mathrm{Al}_{2} \mathrm{O}_{3}-\mathrm{SiO}_{2}-\mathrm{CaSO}_{4}-\mathrm{CaCO}_{3}-\mathrm{H}_{2} \mathrm{O}$. Cem. Concr. Res. 2007;37:1379-1410.

[65] Kühl H. Die hydraulische Erregung granulierter Hochofenschlacken (The hydraulic activation of granulated blastfurnace slags). Zement. 1923;12: 320-322. 